Arch. histol. jap., Vol. 38, No. 4 (1975)

p. $321-334$

Department of Anatomy (Prof. E. Yamada), Faculty of Medicine, University of Tokyo,

Tokyo, Japan

\title{
Studies on Preparation Technique of Human Erythrocytes for Clinical Scanning Electron Microscopy*
}

\author{
Sa'di F. Al-Samarrai**
}

Received July 9, 1975

\begin{abstract}
Summary. Various methods of preparation were tested and modified in order to establish a proper method of preparing normal and pathological human erythrocy tes for scanning electron microscopy. Morphological changes after various preparation techniques, such as echinocy tosis, spherocy tosis, elliptocytosis and knizocytosis were studied and evaluated statistically. The best method, so far obtained to preserve $99 \%$ of normal erythrocytes as biconcave discocytes, was that of venous blood without anticoagulants or acidcitrate-dextrose, washed with physiological saline at $37^{\circ} \mathrm{C}$, fixed in $0.75 \%$ glutaraldehyde in $0.1 \mathrm{M}$ phosphate buffer, $\mathrm{pH} 7.3$ (318 mosmol), postfixed in $1 \%$ osmium tetroxide, dehydrated with graded ethanol and amyl acetate, dried with critical point drying method, and coated with carbon and gold.
\end{abstract}

Although scanning electron microscopy (SEM) has been widely applied in medical research, limited studies have been done on the preparation techniques for this methodology. Except for critical point drying method, most electron microscopists merely applied the same method of preparation as used for transmission electron microscopy (TEM). Histopathological studies on erythrocytes by SEM started very early by SALSBURY and Clarke (1967), before artifacts of poor preparation could be pointed out. BEssis and WEED (1972) reported some artifacts and gave their recommendation for improvement of preparation technique. But no extensive study on this problem has been done yet.

This paper deals with the above mentioned problem by checking all steps of preparation methods which could be applied for SEM of red cells, pointing out induced artifacts and morphological changes and proving their significance statistically.

Nomenclature of red cell shapes used in this paper is adopted from the recent proposal by Bessis (1972).

\section{Materials and Methods}

Samples of capillary and venous blood were obtained from five healthy adults who were confirmed hematologically normal as shown in Table 1. Fresh capillary blood was aspirated with a dry melangeur through a cut in the ear lobe with a sterile surgical blade. One to $3 \mathrm{ml}$ of venous blood was drawn in either a disposal Terumo venoject tube containing $2 \mathrm{mg}$ of dried ethylene-diamine-tetraacetic acid (EDTA), or ordinary disposable syringes containing either one; traces of $0.05 \%$ heparin, $0.3 \mathrm{ml}$ of acid-citrate-dextrose (ACD) or fresh physiological saline at $37^{\circ} \mathrm{C}, 24^{\circ} \mathrm{C}$ and $4^{\circ} \mathrm{C}$. One drop of each sample was mixed with $20 \mathrm{ml}$ of physiological saline at their same

* Partial fulfillment of Doctorate Thesis, University of Tokyo.

** On leave of absence from College of Medicine, University of Baghdad, Baghdad, Iraq. Supported by research scholarship, Japanese Ministry of Education. 
Teble 1. Some hematological data of normal healthy individuals at time of study*

\begin{tabular}{ccccccc}
\hline Subject & $\begin{array}{c}\text { Age in } \\
\text { years }\end{array}$ & Sex & $\begin{array}{c}\mathrm{Hb} \\
(\mathrm{g} / 100 \mathrm{ml})\end{array}$ & Ht $(\%)$ & $\begin{array}{c}\text { Erythrocytes } \\
\left(\times 10^{4}\right)\end{array}$ & $\begin{array}{c}\text { Leukocytes } \\
\left(\times 10^{3}\right)\end{array}$ \\
\hline Y. Y. & 32 & $\mathrm{M}$ & 14.9 & 44.1 & 467 & 4.7 \\
K. K. & 26 & $\mathrm{M}$ & 14.9 & 42.7 & 453 & 4.7 \\
T. K. & 44 & $\mathrm{M}$ & 15.4 & - & 448 & 7.1 \\
T. N. & 39 & $\mathrm{M}$ & 13.6 & 38.6 & 411 & 4.3 \\
S. S. & 33 & $\mathrm{M}$ & 14.3 & 40.3 & 456 & 6.9 \\
\hline
\end{tabular}

* Coulter count, Coulter Inc., USA

temperature. Suspensions were centrifuged, supernatants decanted and sediments resuspended in new saline. This step was repeated twice, with gentle shaking by hand, mainly to remove serum proteins and wash cell surfaces. Then, following the preparation method recommended by FujITA et al. (1971) with some modifications, washed erythrocytes were resuspended in $1 \%$ glutaraldehyde in $0.1 \mathrm{M}$ phosphate buffer, $\mathrm{pH} 7.3$, for $1 \mathrm{hr}$ fixation at room temperature, washed with the same buffer in three changes, postfixed with $1 \%$ osmium tetroxide for $30 \mathrm{~min}$ at $4^{\circ} \mathrm{C}$, and dehydrated with $50,65,75,85,95,99,100 \%$ and three changes of absolute ethanol for $10 \mathrm{~min}$ at each concentration, and with amyl acetate in two changes.

Erythrocytes soaked in amyl acetate and rested on either cover glass or aluminium foil were placed in the high pressure chamber of a JEOL critical point drier, and liquid carbon dioxide was used to replace amyl acetate. Then a water bath $\left(70-80^{\circ} \mathrm{C}\right)$ was used to warm the chamber and raise the pressure to $100 \mathrm{~kg} / \mathrm{cm}^{2}$. The valve was opend slightly for leaking after it was confirmed that $\mathrm{CO}_{2}$ had completely become gas and the specimens were dried. Then dried specimens were placed on a Seltac or Scotch double-side sticky tape in order to fix them on the stubs, and further, the edges were mounted with silver paste. Hitachi HUS-4B vacuum evaporator or JEOL JEE$4 \mathrm{~B}$ vacuum evaporator with an EE-RTS rotating and tilting specimen stage was used for coating with $2-5 \mathrm{~mm}$ of a sharpened pencil of carbon and $1.0-1.5 \mathrm{~cm}$ of gold wire of $0.4 \mathrm{~mm}$ in diameter, rotating and tilting at an angle of $40^{\circ}$.

Specimens were observed with an Hitachi HS-2 scanning electron microscope, Hitachi SSM-2 scanning electron microscope and sometimes with JEOL JEM-100B with scanning attachments model EM-ASID. Accelerating voltage was between 10 to $25 \mathrm{kV}$, working distance was $10 \mathrm{~mm}$ and the specimen holder was tilted at an angle of +10 . Kodak Tri-X PAN 120 films were used for micrography at a direct magnification from 1,500 to 60,000 times. Ten to twenty fields, each containing $20-50$ red cells, were selected at random and examined. More than 300 cells for each category were examined morphologically and, among them, 100 cells were measured for their diameter at the non-tilted axis directly from their negative films. Casio Al-1000 electronic calculator was used for statistical calculation.

Using the same technique described above, effects of direct fixation and osmolarity of fixatives at different percentages were studied by sampling as following:

1. Direct fixation. One drop of venous blood, obtained without EDTA, heparin, ACD or physiological saline, was mixed with $20 \mathrm{ml}$ of $1 \%$ glutaraldehyde in $0.1 \mathrm{M}$ phosphate buffer, $\mathrm{pH} 7.3$, with gentle shaking for $1 \mathrm{hr}$ fixation and proceeded. 
Another drop of venous blood was mixed directly with $20 \mathrm{ml}$ of $1 \%$ osmium tetroxide in $0.1 \mathrm{M}$ phosphate buffer, $\mathrm{pH} 7.3$, for $1 \mathrm{hr}$ fixation without primary fixation with glutaraldehyde, and proceeded also.

2. Osmolarity and percentage of fixative. Five drops of venous blood, washed with physiological saline at room temperature, were fixed for $1 \mathrm{hr}$ in glutaraldehyde of different osmolarities measured by an Advanced Osmometer, Advanced instruments, Inc. Osmolarity charts of MASER et al. (1967) were used occasionally. The following fixatives were used:
a. $0.1 \%$ glutaraldehyde in $0.05 \mathrm{M}$ phosphate buffer, $\mathrm{pH} 7.3$ (138 mosmol)
b. 11
c. $0.5 \%$
$0.1 \mathrm{M}$
(238 mosmol)
d. $0.75 \%$
"I
e. $1.0 \%$
II
f. $2.5 \%$
II
/I
g. $5.0 \%$
/I
II

"/
/
/
"
/
/
h. $0.5 \%$
/I
// (288 mosmol)
// (318 mosmol)
// (367 mosmol)
// (537 mosmol)
// (775 mosmol)
$\begin{array}{ll}\text { i. } / / & \\ \text { j. } / /\end{array}$
// with $3 \%$ sucrose (367 mosmol)
II II
// with 6\% sucrose
(465 mosmol)
" with $10 \%$ sucrose
(573 mosmol)

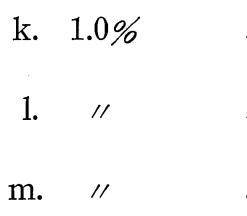
" I
with $3.4 \%$ sucrose
(400 mosmol)
" with $6.8 \%$ sucrose
(525 mosmol)
" with $10.2 \%$ sucrose
(640 mosmol)

Acetone was tried for dehydration also. Some samples of venous blood were dehydrated in 30, 50, 70, 90, 95, 100\% and dried acetone for $10 \mathrm{~min}$ in each concentration, with gentle centrifugation of $1,000 \mathrm{rpm}$ for $5 \mathrm{~min}$. One drop of moderately concentrated suspension of cells in dried acetone, absolute ethanol or propylene oxide was placed on a large cover glass, aluminium foil or hard plastic plates and turned obliquely for quick air drying using an air drier from a distance cautiously without heating.

To confirm the standard shape and size of normal erythrocytes, one drop of fresh venous blood was placed between a slide and coverslip for immediate examination and photography under phase-contrast and dark-field microscopes.

Light microscopic and transmission electron microscopic (TEM) studies were also conducted on the dried erythrocytes for SEM. Scanned hard plastic plates with dried red cells on their surface were embedded in Epon, incubated in an oven at $45^{\circ} \mathrm{C}$ for $24 \mathrm{hrs}$ and at $60^{\circ} \mathrm{C}$ for another $48 \mathrm{hrs}$ for polymerization, and ultrathin sectioned by an ultra-microtome (Porter-Blum). Sections $1 \mu$ in thickness were stained with toluidine blue for light microscopy. The thinner sections, silver-gold in color, were stained with uranyl acetate and lead citrate and viewed with an Hitachi HU-12 electron microscope. 
Table 2. Sampling and shape of normal human erythrocytes

\begin{tabular}{|c|c|c|c|c|c|c|}
\hline \multicolumn{2}{|r|}{ Sample } & $\begin{array}{c}\text { No. of } \\
\text { Erythrocytes }\end{array}$ & $\begin{array}{c}\text { No. of } \\
\text { Discocytes } \\
(\%)\end{array}$ & $\begin{array}{c}\text { No. of } \\
\text { Knizocytes } \\
(\%)\end{array}$ & $\begin{array}{c}\text { No. of } \\
\text { Echinocytes } \\
(\%)\end{array}$ & $\begin{array}{c}\text { No. of } \\
\text { Others } \\
(\%)\end{array}$ \\
\hline \multicolumn{2}{|c|}{ Capillary Blood } & 326 & $11(3.4)$ & 0 & $315(96.6)$ & 0 \\
\hline \multicolumn{2}{|c|}{ Venous Blood $\left(37^{\circ} \mathrm{C}\right)$} & 334 & $332(99.4)$ & 0 & $2(0.6)$ & 0 \\
\hline " & $\prime \prime\left(24^{\circ} \mathrm{C}\right)$ & 390 & $354(90.8)$ & $6(1.5)$ & $30(7.7)$ & 0 \\
\hline "1 & $\prime \prime\left(4^{\circ} \mathrm{C}\right)$ & 384 & $316(82.3)$ & $1(0.3)$ & $60(15.6)$ & $7(1.8)^{*}$ \\
\hline " & $"$ (EDTA) & 309 & $236(76.4)$ & $1(0.3)$ & $72(23.3)$ & 0 \\
\hline " & " (Hep.) & 387 & $180(46.5)$ & 0 & $207(53.5)$ & 0 \\
\hline " & $\prime \prime \quad(\mathrm{ACD})$ & 244 & $15(6.2)$ & $1(0.4)$ & $228(93.4)$ & 0 \\
\hline
\end{tabular}

* Target cells

Table 3. Sampling and diameter of normal human erythrocytes

\begin{tabular}{|c|c|c|c|c|c|}
\hline \multirow{2}{*}{\multicolumn{3}{|c|}{ Sample }} & \multirow{2}{*}{$\begin{array}{c}\text { No. of } \\
\text { Erythrocytes }\end{array}$} & \multicolumn{2}{|c|}{ Diameter $(\mu)$} \\
\hline & & & & Mean & $\mathrm{Se}^{* *}$ \\
\hline \multicolumn{3}{|c|}{ Capillary Blood } & 100 & 5.8 & 0.08 \\
\hline \multicolumn{2}{|c|}{ Venous Blood } & $\left(37^{\circ} \mathrm{C}\right)$ & 100 & 6.8 & 0.02 \\
\hline$" 1$ & 11 & $\left(24^{\circ} \mathrm{C}\right)$ & 100 & 6.8 & 0.05 \\
\hline 11 & "I & $\left(4^{\circ} \mathrm{C}\right)$ & 100 & 6.8 & 0.06 \\
\hline "1 & " & (EDTA) & 100 & 6.1 & 0.07 \\
\hline "I & " & (Hep.) & 100 & 6.4 & 0.07 \\
\hline "I & " & (ACD) & 100 & $5.7^{*}$ & 0.11 \\
\hline
\end{tabular}

* Echinocytes I, II, III are included. $\quad * * \mathrm{Se}=$ Standard error.

Fig. 1. Well preserved biconcave erythrocytes of venous blood obtained and washed with fresh physiological saline at $37^{\circ} \mathrm{C}$ before fixation. $\times 1,300$

Fig. 2. Erythrocytes of capillary blood drawn from a healthy individual by using a dry melangeur, before washing with saline and fixation. Early and advanced echynocytosis caused by glass. $\times 1,300$

Fig. 3. Erythrocytes of venous blood with EDTA. A few echinocytes at various stages are seen. $\times 1,300$

Fig. 4. Erythrocytes of venous blood with heparin. Many echinocytes are found at the early stage. $\times 1,300$

Fig. 5. Erythrocytes of venous blood with ACD. Advanced echinocytosis is noticed. $\times 1,300$

Fig. 6. Erythrocytes of venous blood fixed directly in $1 \%$ glutaraldehyde showing knizocytosis. $\times 1,300$

Fig. 7. Erythrocytes of venous blood fixed directly in $1 \%$ osmium tetroxide showing knizocytosis and multiconcavity. $\times 1,300$

Fig. 8. Erythrocytes of venous blood washed with fresh physiological saline at $24^{\circ} \mathrm{C}$ before fixation in $1 \%$ glutaraldehyde. Many discocytes are well preserved and a few echinocytes are seen. $\times 1,300$ 

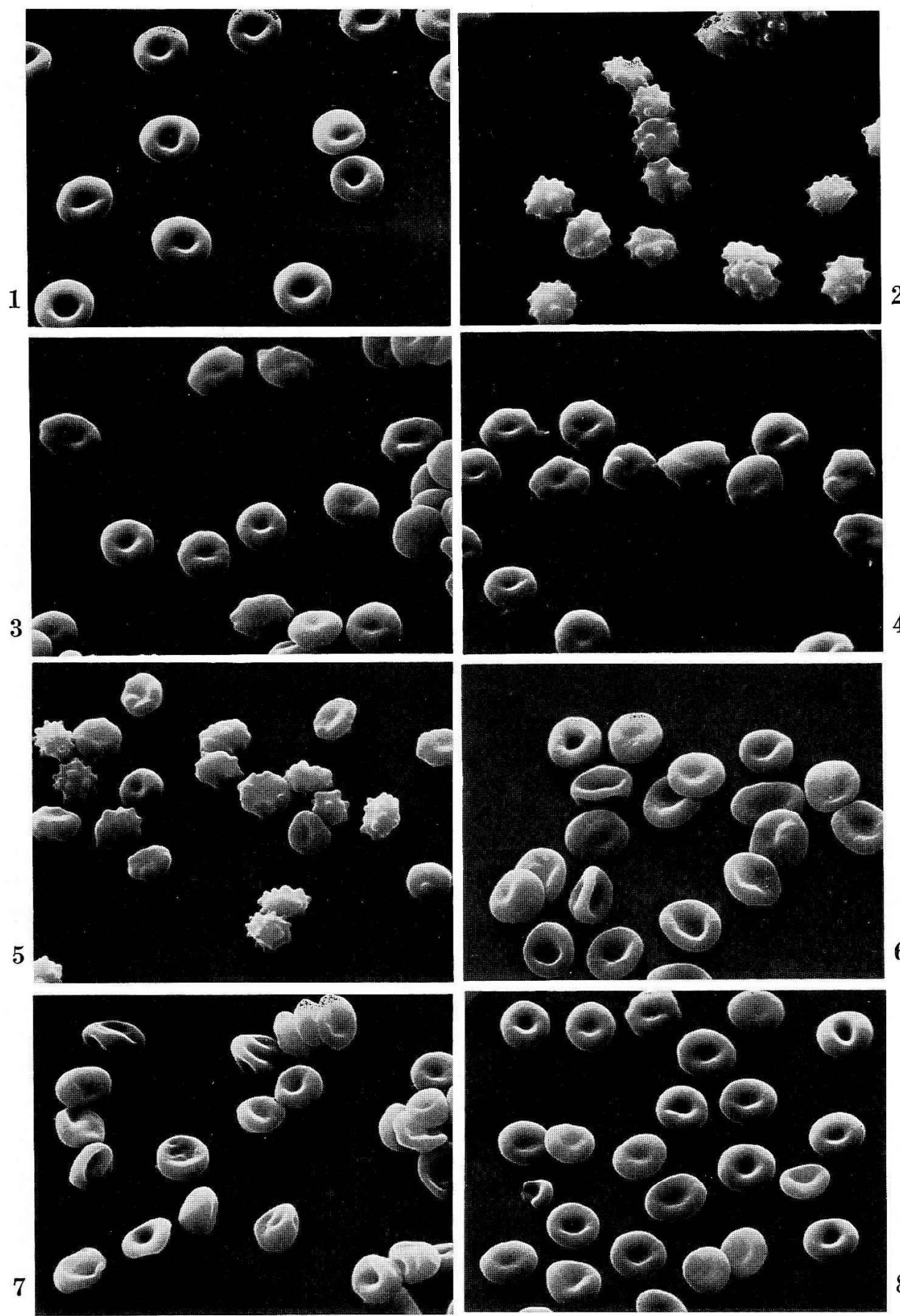


\section{Results}

\section{Sampling}

Erythrocytes were best sampled from venous blood and without anticoagulants, such as heparin, EDTA or ACD (Fig. 1-5). Venous blood washed with fresh physiological saline at $37^{\circ} \mathrm{C}$ showed the highest percentage of nor mal discocytes, $(99.4 \%)$, compared with other samples (Table 2). A high percentage echinocytes, particularly in the early stage (Echinocytosis I \& II), were observed in capillary blood obtained with melangeur (96.6\%) and those samples with ACD (93.4\%), heparin (53.5\%) or EDTA (23.3\%).

Normal discocytes had a smooth peripheral surface but an irregular margin at their central depression and measured about $6.8 \mu$ in diameter (Table 3 ). Though it was difficult to measure the width of the peripheral part and the diameter of the central depression of each discocytes appropriately, they were calculated to be about $1.7 \mu$ and $3.4 \mu$, respectively.

\section{Direct fixation}

Erythrocytes fixed in 1\% glutaraldehyde without washing with physiological saline showed the formation of $35.6 \%$ knizocytosis, $8.2 \%$ multiconcavity and $4.7 \%$ of target cells (Fig. 6 and Table 4). But no change was found in the size of cells and they averaged $6.9 \mu$ in diameter (Table 5). Direct fixation in $1 \%$ osmium tetroxide showed marked multiconcavity $(38.5 \%)$, knizocytosis $(13.5 \%)$, target cells $(7.7 \%)$ and

Table 4. Effects of direct fixation on the shape of erythrocytes (RBC)

\begin{tabular}{|c|c|c|c|c|c|c|c|c|}
\hline Fixative & $\begin{array}{l}\text { Washing } \\
\text { with } \\
\text { Saline }\end{array}$ & $\mathrm{n}$ & $\begin{array}{l}\text { No. of } \\
\text { Dc }(\%)\end{array}$ & $\begin{array}{l}\text { No. of } \\
\mathrm{Kc}(\%)\end{array}$ & $\begin{array}{l}\text { No. of } \\
\mathrm{Mc}(\%)\end{array}$ & $\begin{array}{l}\text { No. of } \\
\mathrm{Tc}(\%)\end{array}$ & $\begin{array}{l}\text { No. of } \\
\text { Ec }(\%)\end{array}$ & $\begin{array}{c}\text { No. of } \\
\text { Others }(\%)\end{array}$ \\
\hline $1 \% \mathrm{GA}$ in $0.1 \mathrm{M} \mathrm{PB}$ & with & 167 & $152(90.8)$ & $2(1.5)$ & 0 & 0 & $13(7.7)$ & 0 \\
\hline$\prime \prime$ & without & 171 & $87(50.9)$ & $61(35.6)$ & $14(8.2)$ & $8(4.7)$ & $1(0.6)$ & 0 \\
\hline $1 \% \mathrm{OsO}_{4}$ in $/ \prime$ & with & 167 & $24(14.4)$ & 0 & 0 & 0 & $?$ & $143(85.6)^{*}$ \\
\hline "1 & without & 104 & $28(26.9)$ & $14(13.4)$ & $40(38.5)$ & $8(7.7)$ & $?$ & $14(13.5)^{* *}$ \\
\hline
\end{tabular}

* Distorted cells with plasticity, elliptocytosis and suspected early echinocytosis.

** Distortion with suspected early echinocy tosis.

n: No. of Erythrocytes Dc: Discocytes Kc: Knizocytes Mc: Multiconcave cells

Ec: Echinocytes GA: Glutaraldehyde PB: Phosphate Buffer $\mathrm{OsO}_{4}$ : Osmium tetroxide

Table 5. Effects of direct fixation on size of erythrocytes (RBC)

\begin{tabular}{lllcc}
\hline \multirow{2}{*}{ Fixative } & \multirow{2}{*}{$\begin{array}{c}\text { Washing } \\
\text { with Saline }\end{array}$} & $\begin{array}{c}\text { No. of } \\
\text { Erythrocytes }\end{array}$ & \multicolumn{2}{c}{ Diameter $(\mu)$} \\
\cline { 4 - 5 } & & & Mean & Se* $^{*}$ \\
\hline $1 \% \mathrm{GA}$ in $0.1 \mathrm{M} \mathrm{PB}$ & with & 100 & 6.8 & 0.05 \\
$1 \% \mathrm{GA}_{\text {in } 0.1 \mathrm{M} \mathrm{PB}}$ & without & 100 & 6.9 & 0.06 \\
$1 \% \mathrm{OsO}_{4}$ in $0.1 \mathrm{M} \mathrm{PB}$ & with & 100 & 7.9 & 0.12 \\
$1 \% \mathrm{OsO}_{4}$ in $0.1 \mathrm{M} \mathrm{PB}$ & without & 100 & 6.8 & 0.10 \\
\hline
\end{tabular}

${ }^{*} \mathrm{Se}=\mathrm{Standard}$ error 
other kinds of distortions (Fig. 7 and Table 4). These cells were about $6.7 \mu$ in diameter.

\section{Washing}

Washing with physiological saline at $24^{\circ} \mathrm{C}$ and $4^{\circ} \mathrm{C}$ before fixation gave results slightly inferior to those samples washed at $37^{\circ} \mathrm{C}$ (Table 2). Echinocytosis $(7.7 \%)$ and rarely knizocytosis $(1.5 \%)$ were found in samples incubated at $24^{\circ} \mathrm{C}$ (Fig. 8), while we observed a higher percentage of echinocytes $(15.6 \%)$ but few target cells $(1.8 \%)$ at $4^{\circ} \mathrm{C}$ (Fig. 9).

\section{Osmolarity of fixative}

Table 6 shows that a very hypotonic fixative (138-238 mosmol) caused spherocytosis (Fig. 10), and cells were $5.3-6.4 \mu$ in diameter (Table 7). Isotonic* (288 mosmol) and slightly hypertonic (318 mosmol) fixatives preserved about $98.5 \%$ of cells as normal discocytes (Fig. 11 and 12, respectively). $1 \%$ glutaraldehyde in $0.1 \mathrm{M}$

Table 6. Osmolarity of fixatives and erythrocytes shape

\begin{tabular}{|c|c|c|c|c|c|c|c|c|}
\hline Fixative & $\begin{array}{l}\text { Osmolarity } \\
\text { (mosmol) }\end{array}$ & $\mathrm{n}$ & $\begin{array}{l}\text { No. of } \\
\text { Dc }(\%)\end{array}$ & $\begin{array}{l}\text { No. of } \\
\operatorname{Kn}(\%)\end{array}$ & $\begin{array}{l}\text { No. of } \\
\operatorname{Ec}(\%)\end{array}$ & \multicolumn{2}{|l|}{$\begin{array}{c}\text { No. of } \\
\text { Others }(\%)\end{array}$} & \\
\hline $0.1 \% \mathrm{GA}$ in $0.05 \mathrm{M} \mathrm{PB}$ & 138 & 267 & $23(8.6)$ & 0 & 0 & $244(91.4)$ & (Sphero & \\
\hline $0.1 \% \mathrm{GA}$ in $0.1 \mathrm{M} \mathrm{PB}$ & 238 & 568 & $547(96.3)$ & $2(0.3)$ & $0(0.2)$ & $18(3.2)($ & /l & ) \\
\hline $0.5 \% \mathrm{GA}$ in $0.1 \mathrm{M} \mathrm{PB}$ & 288 & 526 & $508(96.5)$ & $5(1.0)$ & $2(0.4)$ & $11(2.1)($ & "I & ) \\
\hline $0.75 \% \mathrm{GA}$ in $0.1 \mathrm{M} \mathrm{PB}$ & 318 & $6 \perp 3$ & $605(98.7)$ & $2(0.4)$ & $4(0.7)$ & $2(0.4)($ & "I & ) \\
\hline $1 \% \mathrm{GA}$ in $0.1 \mathrm{M} \mathrm{PB}$ & 367 & 584 & $530(90.8)$ & $9(1.5)$ & $45(7.7)$ & 0 & & \\
\hline $2.5 \% \mathrm{GA}$ in $0.1 \mathrm{M} \mathrm{PB}$ & 537 & 468 & $334(71.4)$ & $2(0.5)$ & $113(24.2)$ & $19(3.9)$ & & \\
\hline $5 \% \mathrm{GA}$ in $0.1 \mathrm{M} \mathrm{PB}$ & $775^{*}$ & 525 & $102(19.4)$ & 0 & $423(80.6)$ & 0 & & \\
\hline
\end{tabular}

n: No. of erythrocytes Dc: Discocytes Kn: Knizocytes Ec: Echinocytes I, II, III Tc: Target cells

* Estimated according to osmolarity charts of MASER et al. (1967)

Table 7. Effects of fixatives of different osmolarities and percentages on size of normal human erythrocytes (Glutaraldehyde)

\begin{tabular}{lcccc}
\hline \multicolumn{1}{c}{ Fixative } & $\begin{array}{c}\text { Osmolarity } \\
\text { (mosmol) }\end{array}$ & $\begin{array}{c}\text { No. of } \\
\text { Erythrocytes }\end{array}$ & \multicolumn{2}{c}{ Diameter $(\mu)$} \\
\cline { 4 - 5 } Mean & Se** \\
\hline $0.1 \%$ GA in 0.05 M PB & 138 & 100 & 5.3 & 0.04 \\
$0.1 \%$ GA in 0.1 M PB & 238 & 100 & 6.4 & 0.05 \\
$0.75 \%$ GA in 0.1 M PB & 288 & 100 & 6.6 & 0.05 \\
$1 \%$ GA in 0.1 M PB & 318 & 100 & 6.7 & 0.05 \\
$2.5 \%$ GA in 0.1 M PB & 537 & 100 & 6.8 & 0.05 \\
$5 \%$ GA in 0.1 M PB & $775^{*}$ & 100 & 7.6 & 0.10 \\
\hline
\end{tabular}

* Estimated according to osmolarity charts of MASER et al. (1967).

** Se $=$ Standard error

* The osmolarity of normal human serum was found, in this study, to be 290 mosmol. 

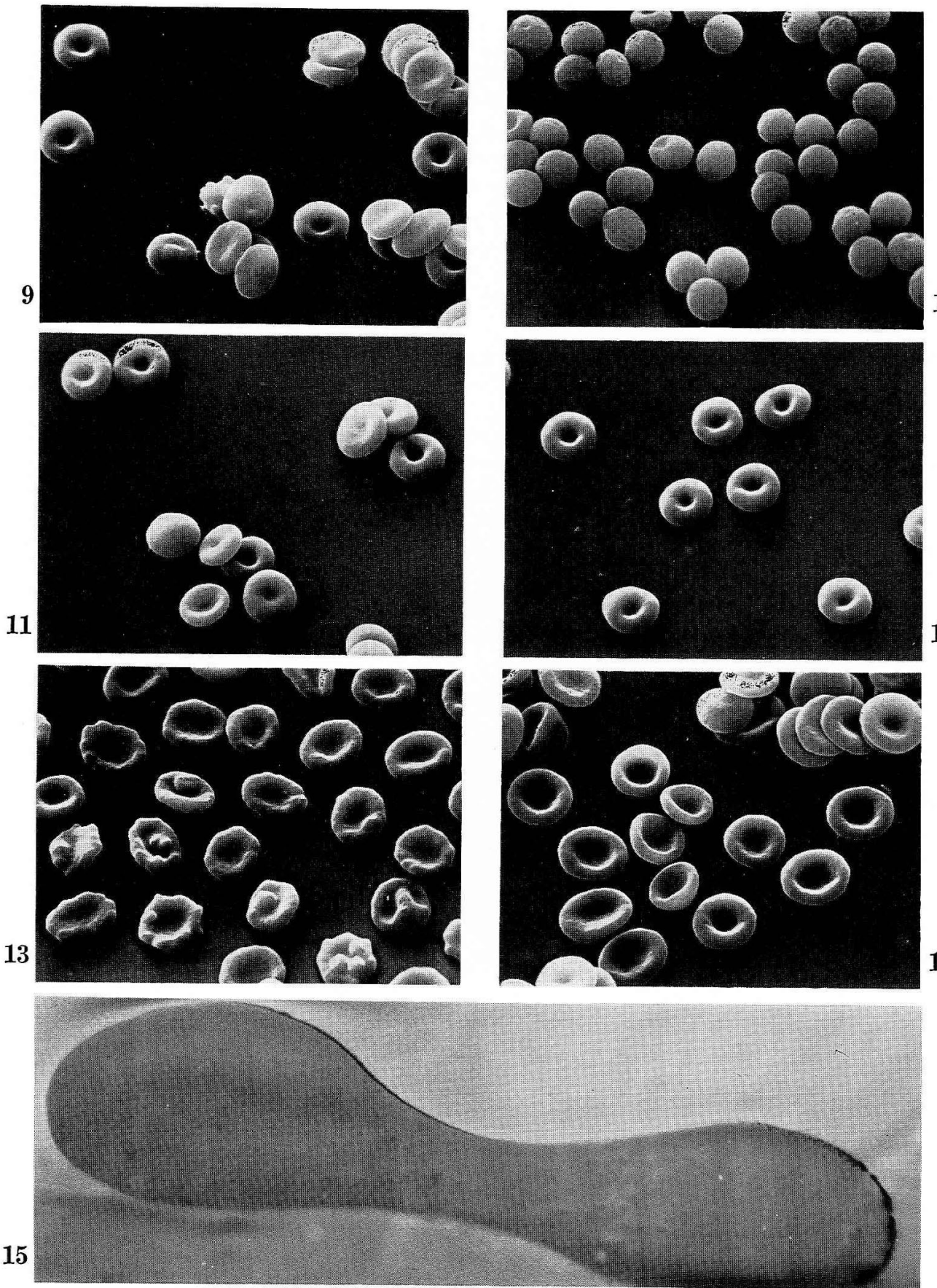
phosphate buffer (367 mosmol) gave fairly good results also but with a shallow and widened central depression (Fig. 8). Very hypertonic fixatives (2.5\% and 5\% glutaraldehyde or 537 and 775 mosmol respectively) induced elliptocytosis with echinocy. tosis and an increase in their diameter (Fig. 13). No remarkable change in shape of cells was found in either isotonic or little hypertonic fixative with sucrose (Fig. 14). But there was an increase in the diameter of cells and their central depression as the osmolarity of such fixatives increased (Table 8).

\section{Dehydration and drying}

Acetone gave fairly good results in dehydrating fixed cells for air drying. But ethanol and amyl acetate were found to be preferable for the critical point drying method. Erythrocytes dried on hard plastic plates could be well observed. No great differences between air drying and critical point drying was found in the case of examing discocytes and echinocytes.

Table 8. Effects of fixatives of different osmolarities and percentages on size of normal human erythrocytes (RBC) (Glutaraldehyde with sucrose)

\begin{tabular}{lcccc}
\hline \multicolumn{1}{c}{ Fixative } & $\begin{array}{c}\text { Osmolarity } \\
(\text { mosmol })\end{array}$ & $\begin{array}{c}\text { No. of } \\
\text { Erythrocytes }\end{array}$ & Mean & Se** \\
\hline 0.5\% GA in 0.1 M PB+3\% Sucrose & 367 & 100 & 7.4 & 0.060 \\
$0.5 \% \mathrm{GA}$ in 0.1 M PB+6\% Sucrose & 465 & 100 & 7.7 & 0.051 \\
$0.5 \% \mathrm{GA}$ in 0.1 M PB+10\% Sucrose & 573 & 100 & 8.0 & 0.063 \\
$1 \% \mathrm{GA}$ in 0.1 M PB+3.4\% Sucrose & $400^{*}$ & 100 & 7.9 & 0.066 \\
$1 \% \mathrm{GA}$ in 0.1 M PB+6.8\% Sucrose & $525^{*}$ & 100 & 8.4 & 0.091 \\
$1 \% \mathrm{GA}$ in 0.1 M PB+10.2\% Sucrose & $640^{*}$ & 100 & 9.0 & 0.077 \\
\hline
\end{tabular}

* Estimated according to osmolarity charts of MASER et al. (1967)

** $\mathrm{Se}=$ Standard error

Fig. 9. Erythrocytes of venous blood washed with fresh physiological saline at $4^{\circ} \mathrm{C}$ before fixation in $1 \%$ glutaraldehyde, showing a few echinocytes and target cells. $\times 1,300$

Fig. 10. Erythrocytes of venous blood washed with fresh physiological saline at $24^{\circ} \mathrm{C}$ and fixed in $0.1 \%$ glutaraldehyde in $0.05 \mathrm{M}$ phosphate buffer (138 mosmol), showing marked spherocytosis. $\times 1,300$

Fig. 11. Erythrocytes of venous blood washed with fresh physiological saline at $24^{\circ} \mathrm{C}$ and fixed in $0.5 \%$ glutaraldehyde in $0.1 \mathrm{M}$ phosphate buffer (288 mosmol). Many cells maintained their biconcavity but with slight peripheral swelling. $\quad \times 1,300$

Fig. 12. Erythrocytes of venous blood washed with fresh physiological saline at $24^{\circ} \mathrm{C}$ and fixed in $0.75 \%$ glutaraldehyde in $0.1 \mathrm{M}$ phosphate buffer (31.8 mosmol) showing good preservation of the shape and size consistent with those of fresh blood. $\times 1,300$

Fig. 13. Erythrocytes of venous blood washed with fresh physiological saline at $24^{\circ} \mathrm{C}$ and fixed in $2.5 \%$ glutaraldehyde in $0.1 \mathrm{M}$ phosphate buffer (558 mosmol) showing elliptosis and echinocytosis. $\times 1,300$

Fig. 14. Erythrocytes of venous blood washed with fresh physiological saline at $24^{\circ} \mathrm{C}$ and fixed in $0.5 \%$ glutaraldehyde in $0.1 \mathrm{M}$ phosphate buffer with $10 \%$ sucrose $(573$ mosmol) showing elliptosis without echinocytosis. $\times 1,300$

Fig. 15. Erythrocyte maintaining its biconcavity after being dried on a plastic plate, coated with carbon and gold, scanned, epon embedded and sectioned for TEM. $\quad \times 18,000$ 


\section{Scanning electron microscopy}

It was noticed that low accelerating voltage at $10 \mathrm{kV}$ gave more clear images of the cell surface than at $20 \mathrm{kV}$. Too long exposure of the specimens to electron beam caused cellular surface damage particularly at deep and not enough coated central depression.

\section{Transmission electron microscopy}

Erythrocytes dried on hard plastic plates and sectioned for both light microscopy and TEM maintained their normal biconcavity when they were prepared properly (Fig. 15). Thickness and extent of coating could be examined in ultrathin sections. It was found that coating does not reach deep parts of the central depression. Furthermore, the coating was granular in appearance and not uniform in thickness.

\section{Discussion}

\section{Sampling}

Discocyte-echinocyte transformation in capillary blood aspirated with a dry melangeur could be attributed to the glass effect noticed by many authors (FURCHGOTT and Ponder, 1940; Ponder, 1948; Trotter, 1956; Ponder and Ponder, 1962; Bessis and Prenant, 1972; Brecher and Bessis, 1972; Weed and Chailly, 1972). We found that echinocytosis could be eliminated by direct transfer of a drop of capillary blood on the edge of a sharp surgical blade to physiological saline. BEssis (1972) classified echinocytosis into five stages: Echinocytosis I, II, III and Sphero-echinocytosis I, II. This echinocytosis was assumed to precede lysis (Ponder, 1948, 1955).

Echinocytogenic substances were found in the plasma containing heparin, citrate or EDTA (FEO, 1972). Heparin has no erythrocyte preservation effect since it lacks dextrose and its anticoagulant effect is neutralized by thromboplastic and antiheparin materials liberated by the cellular elements of the blood (PERKINs et al., 1961). It has been reported that $\mathrm{ACD}$, due to its citrate content, decreases the level of ionized calcium and will lead to a cardiac standstill if ACD blood is pumped directly into the coronary arteries of a patient (Williams et al., 1972). DyckerhofF et al., (1944), who were the first to investigate the anticoagulant effect of EDTA, and many others (Dillard et al., 1951; Proecher, 1951; Hadley and WeIss, 1955) found that EDTA salts preserve the cellular elements much better than other anticoagulants or oxalate. We found that EDTA caused less echinocytosis than heparin or ACD. Further extensive morphological study on the immediate effects of EDTA, heparin and ACD on erythrocytes is needed. But since our data indicated that excellent morphological preservation of cells could be obtained with the presence of physiological saline only, sampling of venous blood without anticoagulants or ACD is recommended.

\section{Direct fixation}

Other types of red blood cells than biconcave discocytes in normal blood were reported by some SEMists who fixed blood directly in glutaraldehyde and these were regarded as normal (Tokunaga et al., 1969; Hattori, 1972). Bessis and WeEd (1972) regarded such types as cup-shaped, target cells and knizocytes as artifacts if seen in 
normal blood; and attributed those deformations to bad preparation or inadequate direct fixation in glutaraldehyde. But such deformities like knizocytosis could be eliminated simply by washing the normal erythrocytes with fresh physiological saline before fixation with glutaraldehyde. Thus, it is now evident that such types are normal with "functional" deformity due to their elasticity in the blood stream, with no time to recover their resting biconcave form before direct fixation.

The marked distortion in the shape of erythrocytes noted after osmium fixation, might be related to some alterations in the cell membranes induced by osmium tetroxide solutions, such as enlargement of equivalent pore size and free passage of ions and small molecules (WoOD and LuFT, 1965), or diminishment in the residual helical content of the red blood cell membrane (LENARD and SINGER, 1968) and finally destruction by osmotic activity (Bone and Denton, 1971).

\section{Washing}

This important first step in sample preparation has been neglected by many researchers. We would like to emphasize that erythrocytes should be washed in a good amount of fresh physiological saline before fixation in order to remove serum proteins, clean their surface and give them time to recover their natural form. Recently, morphological changes of erythrocytes in vitro have been examined at $37^{\circ} \mathrm{C}$ by many authors (LichtmAn and WEED, 1972; FEo, 1972). This study confirmed that erythrocytes washed with saline at $37^{\circ} \mathrm{C}$ showed the highest percentage of normal biconcave discocytes when compared with those washed at room temperature or at $4^{\circ} \mathrm{C}$.

\section{Osmolarity of fixative}

Pure glutaraldehyde is essential for optimal fixation (SABAtini et al., 1964). Impurity increases spontaneously under ordinary conditions of storage (Aso and Аiтo, 1962; ANDERSON, 1967). We confirmed that osmolarity of the fixative increased rapidly within a few hrs after dilution. Therefore, fresh and pure glutaraldehyde should be used; and $\mathrm{pH}$ and osmolarity should be measured immediately before fixation (MAser et al., 1967). Phosphate buffer was used because it is non-toxic and its buffering capacity at $\mathrm{pH} 7.4$ is strong. Though the ideal fixative should allow the cell to neither swell nor shrink during fixation, there has been no general agreement on the best tonicity of fixatives. Many authors preferred very hypertonic fixatives (SAbatini et al., 1963; Burgos et al., 1967; Carteaud et al., 1973). Some authors recommended $1 \%$ glutaraldehyde in $0.1 \mathrm{M}$ phosphate buffer which is still hypertonic (Tokunaga et al., 1969; Bessis and Weed, 1972). But Salsbury and Clarke (1967) used $0.5 \%$ phosphate buffered glutaraldehyde which we confirmed to be isotonic and ARNOLD et al. (1971) as low as $0.1 \%$ krebs buffered glutaraldehyde. Our conclusion in this study is that slightly hypertonic fixative $(0.75 \%$ glutaraldehyde in $0.1 \mathrm{M}$ phosphate buffer, 7.3, or 320 mosmol) is the ideal to preserve the red cells without swelling or shrinkage. They were identical in shape and size to erythrocytes of fresh venous blood examined under phase-contrast and dark-field microscopes.

SABAtini et al. (1963) recommended the addition of sucrose to formaldehyde fixative for optimal preservation of the ultrastructure. We found that $0.5 \%$ glutaraldehyde in $0.1 \mathrm{M}$ phosphate buffer with $3 \%$ sucrose or 367 mosmol, though hypertonic, preserved erythrocytes well. The increase of osmolarity by addition of sucrose 
to 640 mosmol caused shrinkage of the cells and widening of their central depression but without echinocytosis. This result means that increasing tonicity of the fixatives or solutions with sucrose causes less damage to the cell membrane.

\section{Dehydration and drying}

Acetone dehydration and air drying was recommended for SEM in general (BARBer and Boyde, 1968; Fujit A et al., 1968, 1971). But the critical point drying method, which was first developed by ANDERSON in 1951, removes the water from the specimen without damaging the surface tension, and hence can be expected to preserve the form of the cell. This technique has been applied successfully to SEM (BoydE and Wood, 1969). In the present study, no remarkable difference in the erythrocyte morphology was found between air drying and critical point drying methods. This could be attributed to the fact that the erythrocyte has a more stable structure than the ordinary cells. In the future, however, more subtle structural changes due to air drying may possibly be detected under high resolution SEMs.

\section{Transmission electron microscopy}

HATTORI (1972) speculated that erythrocytes might become uniconcave on a glass plate, and their hidden surface being flattened when they are dried for SEM. Our correlative study with SEM, light microscopy and TEM did not show such deformity and we found that red cells maintain their biconcavity after drying provided that they have been prepared and dehydrated properly.

\section{Clinical scanning electron microscopy}

As for clinical application of our method, it was used for morphological study of erythrocytes of paroxysmal nocturnal hemoglobinuria and was found satisfactory for the identification of the abnormal cells (AL-SAmARRAI, 1974).

Acknowledgment. The author is greatly indebted to Prof. Eichi Yamada of the Department of Anatomy, University of Tokyo for his invaluable advice during the whole course of study. He is thankful to Mr. Y. FukudA, Department of Anatomy, University of Tokyo, and Mr. T. NASHIRo, Department of Pathology, Cancer Institute, Tokyo, for their skillful technical assistance. Also he wishes to thank all those who generously offered their blood for this study, or extended any sort of help.

\section{References}

Al-Samarrai, S. F. : Some observations on human erythrocytes by scanning electron microscopy. Acta anat. nippon. 49:151 (1974). Abstract.

: Scanning electron microscopic studies on human erythrocytes. Thesis, University of Tokyo, 1974.

- : Scanning electron microscopic studies on erythrocytes of paroxysmal nocturnal hemoglobinuria. J. clin. Electron Microsc. $7:$ 466-467 (1974).

Anderson, P. J.: Purification and quantitation of glutaraldehyde and its effect on several enzyme activities in skeletal muscle. J. Histochem. Cytochem. 15: 652-661 (1967).

Anderson, T. F.: Techniques for the preservation of three-dimentional structure in preparing specimens for the electron microscope. Trans. New York Acad. Sci. 13: 130-134 (1951). 
Arnold, J. D., A. E. Berger and O. L. Allison : Some problems of fixation of selected biological samples for S. E. M. examination. In: (ed. by) O. Johari and I. Corvin: Scanning electron microscopy /1971. Chicago, IIT Res. Inst., 1971. (p. 249-256).

Aso, C. and Y. Aito: Studies on the polymerization of bifunctional monomers. II. Polymerization of glutaraldehyde. Makromol. Chem. 58: 195-203 (1962).

Barber, V. C. and A. Boyde: Scanning electron microscopic studies on cilia. Z. Zellforsch. 84: 269-284 (1968).

Bessis, M. : Red cell shapes-An illustrated classification and its rationale. Nouv. Rev. fr. Hemat. 12: 721-746 (1972).

Bessis, M. et M. Pernant: Topographie de 1'appartion des spicules dans les erythrotes crenels (Echinocytes). Nouv. Rev. fr. Hemat. 12: 351-364 (1972).

Bessis, M. and R. I. Weed: Preparation of red blood cells for SEM-A survey of various artifacts. In: (ed. by) O. Johari: SEM/1972. Chicago. IIT Res. Inst., 1972. (p. 289-296).

Bone, Q. and E. J. Denton: The osmotic effects of electron microscopic fixatives. J. Cell Biol. 49: 571-581 (1971).

Boyde, A., S. J. Jones and E. Bailey : Bibliography of biomedical applications of scanning electron microscopy. In: (ed. by) O. Johari: SEM/1973. Chicago, IIT Res. Inst., 1973. (p. 697-734).

Boyde, A. and C. Wood: Preparation of animal tissues for surface-scanning electron microscopy. J. Microscopy 90: 221-249 (1969).

Brecher, G. and M. Bessis : Present status of spiculed red cells and their relationship to discocyteechinocyte transformation: A critical review. Blood 40: 333-343 (1972).

Burgos, M. H. : Studies on paraformaldehyde fixation for electron microscopy. I. Effect of concentration on ultrastructure. J. Microscopie 6: 457-468 (1967).

Carteaud, J. P., M. D. Muir and G. Cataigne: A morphological investigation in the SEM of haemagglutination with influenza and vaccinia viruses. In: (ed. by) O. Johari: SEM/1973. Chicago, IIT Res. Inst., 1973. (p. 497-504).

Dillard, G. H. L., G. Brecher and E. D. Cronkite : Separation, concentration and transfusion of platelets. Proc. Soc. Exp. Biol. Med. 78: 796-799 (1951).

Dyckerhoff, H., R. Marx und B. Ludwig: Über den Wirkungsmechanismus und die Verwendbarkeit einiger bluterinnungschemmender organischer Substanzen. Z. Deut. Ges. Exp. Med. 110: 412-422 (1944).

Feo, C.: The role of lysolecithin formed in plasma on the discocyte-echinocyte transformation. A commentary. Nouv. Rev. fr. Hemat. 12: 757-760 (1972).

Fujita, T., H. Inoue and T. Kodama : Scanning electron microscopy of the normal and rheumatoid synovial membranes. Arch. histol. jap. 29: 511-522 (1968).

Fujita, T,. J. Tokunaga and H. Inoue: Atlas of scanning electron microscopy in medicine. Tokyo, Igaku Shoin Ltd., 1971.

Furchgott, R. F. and E. Ponder: Disk-sphere transformation in mammalian red cells. II. The nature of the anti-sphering factor. J. exp. Biol. 17: 117-127 (1940).

Hadley, G. G. and S. S. Weiss : Further notes on use of salts of ethylenediamine tetraacetic acid (EDTA) as anticoagulants. Amer. J. clin. Pathol. 25: 1090-1093 (1.955)

Hattori, A.: Scanning electron microscopy of human peripheral blood cells. Acta hemat. jap. 35: 457-482 (1972).

Lenard, J., and S. J. Singer: Alteration of the conformation of proteins in red blood cell membranes and in solution by fixatives used in electron microscopy. J. Cell Biol. 37: 117-121 (1968).

Lichtman, M. A. and R. I. Weed : Divalent cation content of normal and ATP-depleted erythrocyte membranes. Nouv. Rev. franç. Hematol. 12: 799-814 (1972).

Maser, M. D., T. F. Powell and C. W. Philpott: Relationships among pH, osmolarity, and concentration of fixative solutions. Stain Technol. 42: 175-182 (1967). 
Morel, F. M,. R. F. Baker and H. Wayland : Quantitation of human red cell fixation by glutaraldehyde. J. Cell Biol. 48: 91-100 (1971).

Perkins, H. A., M. R. Rolfs and D. J. Acra : Studies on bank blood collected and stored under various conditions with particular reference to its use in open heart surgery. Transfusion 1 : 151-162 (1961).

Ponder, E. : Hemolysis and related phenomena. New York, Grune and Stratton, 1948. : Red cell structure and its breakdown. Wein, Springer-Verlag, 1955.

Ponder, E. et R. Ponder: Transformation disque-sphere des globules rouges humaines entre deux surfaces de verre. Nouv. Rev. fr. Hemat. 2: 223-229 (1962).

Proescher, F.: Anti-coagulant properties of ethylene bis-iminodiacetic acid. Proc. Soc. Exp. Biol. Med. 76: 619-620 (1951).

Sabatini, D. D,. K. Bensch and R. J. Barnett : Cytochemistry and electron microscopy-The preservation of cellular ultrastructure and enzymatic activity by aldehyde fixation. J. Cell Biol. 17: 19-58 (1963).

Sabatini, D. D., F. Miller and R. J. Barnett : Aldehyde fixation for morphological preservation and enzymical studies with the electron microscope. J. Histochem. Cytochem. 12: 57-71 (1964).

Salsbury, A. J. and J. A. Clarke: New method for detecting changes in the surface appearance of human red blood cells. J. clin. Pathol. 20: 603-610 (1967).

Tokunaga, J., T. Fujita and A. Hattori : Scanning electron microscopy of normal and pathological human erythrocytes. Arch. histol. jap. 31: 21-35 (1969).

Trotter, W. D.: The slide-coverslip disc-sphere transformation in mammalian erythrocytes. Brit. J. Haematol. 2: 65-74 (1956).

Weed, R. I. and B. Chailley : Calcium-pH interactions in the production of shape change in erythrocytes. Nouv. Rev. fr. Hemat. 12: 775-788 (1972).

Williams, W. J., E. Beutler, A. J. Erslev and R. W. Rundles: Hematology. McGraw-Hill, 1972. (p. 1312).

Wood, R. L. and J. H. Luft: The influence of buffer systems on fixation with osmium tetroxide. J. Ultrastr. Res. 12: 22-45 (1965).

Dr. Sa'di F. Al-SAMARRAi

Unit of Electron Microscopy

Medical Research Centre

College of Medicine

University of Baghdad

Baghdad, Iraq 